\title{
OPTIMASI FORMULA NANOEMULGEL EKSTRAK DAUN PIDADA MERAH (Sonneratia Caseolaris L) DENGAN VARIASI GELLING AGENT
}

\author{
Hajrah $^{1 *}$, Lisna Meylina ${ }^{1}$, Riski Sulistiarini ${ }^{1}$, Lia Puspitasari ${ }^{1}$, Awal Prichatin Kusumo ${ }^{2}$ \\ ${ }^{1}$ Fakultas Farmasi Universitas Mulawarman, Samarinda, 75119, Kalimantan Timur \\ ${ }^{2}$ Balai Besar Penelitian Dan Pengembangan Tanaman Obat Dan Obat Tradisional Kementerian Kesehatan \\ Corresponding author email : hajrahsuhardi@gmail.com
}

\begin{abstract}
Gel formulation can either be obtained by formulating some types of gelling, but the most important thing to consider is the choice of gelling agent. HPMC (Hydroxy Propyl Methyl Cellulose), Carbopol 960 and Viscolam MAC 10 is a gelling agent that is commonly used in the production of cosmetics and drugs, because it can produce a clear gel, easily soluble in water, and has a toxicity is low. This study aims to obtain an appropriate gelling agent as a carrier nanoemulgel red pidada leaf extract which has physical stability in accordance with the requirements established. Nanoemulgel Formulations made with variations of gelling agent used further evaluation include the physical properties organoleptic test, homogeneity, dispersive power, $\mathrm{pH}$, and viscosity. Evaluation base gel selected for 30 days. The results of stability tests show the base gel with viscolam MAC 10 have good standards for viscosity, $\mathrm{pH}$, dispersive power, homogeneity and organoleptic.
\end{abstract}

Keyword: Sonneratia caseolaris L, nanoemulgel, gelling agent

ABSTRAK

Sediaan gel yang baik dapat diperoleh dengan cara memformulasikan beberapa jenis bahan pembentuk gel, namun yang paling penting untuk diperhatikan adalah pemilihan gelling agent. HPMC (Hidroxy Propyl Methyl Cellulose), Karbopol 960 dan Viskolam MAC 10 merupakan gelling agent yang sering digunakan dalam produksi kosmetik dan obat, karena dapat menghasilkan gel yang bening, mudah larut dalam air, dan mempunyai ketoksikan yang rendah. Penelitian ini bertujuan untuk memperoleh gelling agent yang sesuai sebagai pembawa nanoemulgel ekstrak daun pidada merah yang memiliki kestabilan fisika yang sesuai dengan persyaratan yang telah ditetapkan. Formulasi nanoemulgel dibuat dengan variasi gelling agent yang digunakan selanjutnya dilakukan evaluasi sifat fisika yang meliputi uji organoleptis, homogenitas, daya sebar, $\mathrm{pH}$, dan viskositas. Evaluasi basis gel terpilih dilakukan selama 30 hari. Hasil yang diperoleh dari uji stabilitas menunjukan basis gel dengan viskolam MAC 10 memiliki standar yang baik untuk viskositas, $\mathrm{pH}$, daya sebar, homogenitas dan organoleptis.

Kata Kunci: Sonneratia caseolaris L , Nanoemulgel, Gelling agent

Submit : 4 April 2017

Accepted: 18 July 2017

DOI: https://doi.org/10.25026/jsk.v2i2.52

\section{PENDAHULUAN}

Gel mempunyai potensi lebih baik sebagai sarana untuk mengelola obat topikal dibandingkan dengan salep ataupun krim, karena gel tidak lengket, memerlukan energi yang tidak besar untuk formulasi, stabil, dan mempunyai estetika yang bagus. Sediaan gel yang baik dapat diperoleh dengan cara memformulasikan beberapa jenis bahan pembentuk gel, namun yang paling penting untuk diperhatikan adalah pemilihan gelling agent [1]. Dalam formulasi gel, komponen gelling agent merupakan faktor kritis yang dapat mempengaruhi sifat fisika gel yang dihasilkan.

Untuk mendapatkan formula sediaan nanoemulgel yang stabil secara fisik maka dilakukan sudatu optimasi basis nanoemulgel dengan menggunakan variasi jenis gelling agent. Stabilitas 
nanoemulgel dapat dilihat dari hasil evaluasi meliputi uji organoleptis, homogenitas, daya sebar, $\mathrm{pH}$, dan viskositas. Berdasarkan hal tersebut dapat dirumuskan permasalahan sebagai berikut, gelling agent manakah yang sesuai dan stabil sebagai pembawa dalam sediaan nanoemulgel ekstrak daun pidada merah.

Penelitian ini bertujuan untuk memperoleh gelling agent yang sesuai sebagai pembawa nanoemulgel ekstrak daun pidada merah yang memiliki kestabilan fyang sesuai dengan persyaratan yang telah ditetapkan.

\section{Metode Penelitian}

\section{Lokasi dan Waktu Penelitian}

Penelitian ini dilaksanakan di Laboratorium Penelitian dan Pengembangan FARMAKA TROPIS Fakultas Farmasi Universitas Mulawarman, Samarinda, Kalimantan Timur selama 2 bulan yaitu bulan September-Oktober 2016.

\section{Bahan}

Bahan yang digunakan dalam penelitian adalah fasa minyak nanoemulsi ekstrak daun Pidada Merah (Sonneratia caseolaris L), aquades, aqudeion, HPMC (Hydroxy Propyl Methyl Cellulose), Viskolam MAC 10, Karbopol 940, Trietanolamin, propilenglikol, gliserin, metil paraben dan propil paraben.

\section{Optimasi sediaan formulasi nanoemulgel dengan variasi gelling agent}

Optimasi sediaan formulasi nanoemulgel dilakukan menggunakan variasi gelling agent yaitu HPMC, Carbopol 940 dan Viscolam MAC 10. Sejumlah HPMC dan Karbopol 940 ditaburkan di atas air, kemudian dibiarkan sesuai dengan waktu optimum masingmasing basis gel, diaduk hingga terbentuk masa gel. Setelah mengembang pada basis Carbopol 940 ditambahkan trietanolamin sampai terbentuk masa gel yang jernih.
Pada basis Viscolam MAC 10 ditambahkan air dan diteteskan trietanolamin hingga terbentuk masa gel. Fasa minyak nanoemulsi ekstrak daun pidada merah dilarutkan terlebih dahulu dalam air ditambahkan ke dalam basis kemudian ditambahkan eksipien lain dalam keadaan terlarut, setelah itu diaduk hingga terbentuk gel dengan konsistensi yang baik. Nanoemulgel yang telah dibuat dievaluasi meliputi uji organoleptis, homogenitas, $\mathrm{pH}$, dan viskositas. Evaluasi basis nanoemulgel terpilih dilakukan selama 30 hari.

\section{Evaluasi Kestabilan Basis Gel}

Pengujian organoleptik dilakukan dengan cara pengamatan langsung bentuk, warna, dan bau dari gel yang dibuat. Gel biasanya jernih dengan konsistensi setengah padat

Pengukuran viskositas yaitu dengan Viskometer Rheosys. Sebanyak $15 \mathrm{~mL}$ gel dimasukkan kedalam wadah silinder, kemudian viskositasnya diukur dengan viskometer yang dilengkapi dengan spindel $(25 \mathrm{~mm}$ Concentric Cylinders) dengan kecepatan $10 \mathrm{rpm}$.

Pengukuran $\mathrm{pH}$ sediaan dilakukan dengan menggunakan $\mathrm{pH}$ meter, dengan cara alat terlebih dahulu dikalibrasi dengan menggunakan larutan dapar standar $\mathrm{pH}$ netral $(\mathrm{pH} 7,00)$ dan larutan dapar $\mathrm{pH}$ asam $(\mathrm{pH} 4,00)$ hingga alat menunjukan harga $\mathrm{pH}$ tersebut. Kemudian elektroda dicuci dengan air suling, lalu dikeringkan dengan kertas tissue. Selanjutnya elektroda dicelupkan kedalam basis gel, sampai alat menunjukkan harga $\mathrm{pH}$ yang konstan. Angka yang ditunjukkan $\mathrm{pH}$ meter merupakan harga $\mathrm{pH}$ sediaan [5]. $\mathrm{pH}$ sediaan basis gel harus sesuai dengan $\mathrm{pH}$ kulit yaitu 4,5-6,5.

Pengujian homogenitas dilakukan dengan cara mengoleskan sampel gel pada sekeping kaca atau bahan transparan lain yang cocok, sediaan harus menunjukkan susunan yang homogen dan tidak terlihat 
adanya butiran kasar.

\section{Analisis Data Penelitian}

Hasil penelitian disajikan dalam bentuk tabel nilai rata-rata \pm standar deviasi serta grafik.

\section{Hasil dan Pembahasan}

Pada penelitian ini dilakukan evaluasi basis gel dan gel yang telah ditambahkan nanoemulsi. Formulasi nanoemulgel dengan menggunakan variasi gelling agent yaitu HPMC, Karbopol 960, dan Viskolam MAC 10 dengan konsentrasi masing-masing secara berurutan ialah 5\%, 1\%, dan $20 \%$.

Tabel 1. Rancangan Formulasi Basis Gel

\begin{tabular}{lcccccc}
\hline \multirow{2}{*}{ Komposisi (\%) } & \multicolumn{7}{c}{ Formula } \\
\cline { 2 - 6 } & F1 & F2 & F3 & F4 & F5 & F6 \\
\hline Ekstrak dalam & - & - & - & 1 & 1 & 1 \\
fase minyak & & - & - & 5 & - & - \\
nanoemulsi & 5 & 1 & - & - & 1 & - \\
HPMC & - & - & 20 & - & - & 20 \\
Carbopol 940 & - & 5 & 5 & 5 & 5 & 5 \\
Viskolam MAC & 5 & 15 & 15 & 15 & 15 & 15 \\
10 & 15 & 0,2 & 0,2 & 0,2 & 0,2 & 0,2 \\
Gliserin & 0,2 & 0,05 & 0,05 & 0,05 & 0,05 & 0,05 \\
Propilenglikol & 0,05 & 100 & 100 & 100 & 100 & 100 \\
Metil Paraben & 100 & & & & & \\
Propil Paraben & & & & & & \\
Aquadest ad & &
\end{tabular}

Keterangan $:(-)=$ Tidak diberikan

Tabel 2 Hasil Evaluasi Penampilan Sediaan Nanoemulgel

\begin{tabular}{lcccccc}
\hline \multirow{2}{*}{ Parameter } & \multicolumn{7}{c}{ Formula } \\
\cline { 2 - 7 } & F1 & F2 & F3 & F4 & F5 & F6 \\
\hline Bau & khas & khas & Khas & khas & khas & khas \\
Fisik & AKT & K & K & C & C & AKT \\
Warna & transparan & transparan & transparan & hijau & hijau & hijau \\
Homogenitas & homogen & homogen & homogen & homogen & homogen & homogen \\
pH & $6.48 \pm 0.06$ & $4.83 \pm 0.12$ & $6.12 \pm 0.07$ & $6.48 \pm 0.06$ & $5.83 \pm 0.12$ & $6.12 \pm 0.07$ \\
Viskositas (P.Sa) & $3.41 \pm 0.33$ & $5.49 \pm 0.28$ & $5.83 \pm 0.12$ & $2.21 \pm 0.32$ & $2.57 \pm 0.09$ & $3.10 \pm 0.04$ \\
\hline
\end{tabular}

Hasil evaluasi menunjukkan bahwa ketiga basis gel memiliki bau yang khas, warna yang transparan (basis gel tanpa nanoemulsi ekstrak) serta berwarna hijau (basis gel dengan nanoemulsi ekstrak), mempunyai homogenitas yang baik tanpa adanya butiran kasar yang menggumpal. Dari pengukuran $\mathrm{pH}$ gel blanko dan nanoemulgel ekstrak terdapat penurunan nilai $\mathrm{pH}$ jika dibandingkan antara $\mathrm{pH}$ gel blanko dengan nanoemulgel ekstrak. Hal ini kemungkinan disebabkan oleh $\mathrm{pH}$ nanoemulsi ekstrak yang agak asam $(\mathrm{pH} \pm$ 4.5) tetapi secara keseluruhan bahwa seluruh sediaan yang diperoleh mempunyai rentang $\mathrm{pH}$ yang masih dalam 
diterima oleh kulit (pH kulit 4,5 - 6,5). Penurunan nilai $\mathrm{pH}$ ini juga menyebabkan penurunan viskositas dari sediaan dikarenakan nilai $\mathrm{pH}$ berpengaruh pada proses terbentuknya massa gel dari gelling agent yang digunakan. Dari ketiga jenis gelling agent yang digunakan terpilihlah viskolam MAC 10 sebagai gelling agent yang akan dievaluasi stabilitasnya selama penyimpanan 30 hari.

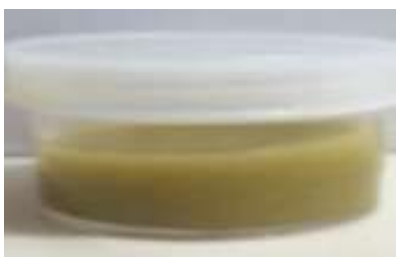

Gambar 1. Sediaan nanoemulgel menggunakan gelling agent viskolam MAC $1020 \%$

Berikut adalah hasil uji stabilitas sedian nanoemulgel terpilih pada penyimpanan di suhu $40^{\circ} \mathrm{C}$ selama 30 hari.

Tabel 3. Hasil Stabilitas Sediaan Nanoemulgel Terpilih

\begin{tabular}{lcccccccc}
\hline \multirow{2}{*}{ Parameter } & \multicolumn{10}{c}{ Hari ke- } \\
\cline { 2 - 9 } Warna & Hijau & Hijau & Hijau & Hijau & Hijau & Hijau & Hijau & Hijau \\
Bau & keruh & keruh & keruh & keruh & keruh & keruh & keruh & keruh \\
Homogenitas & Khas & Khas & Khas & Khas & Khas & Khas & Khas & Khas \\
Sineresis & V & V & V & V & V & V & V & V \\
Pertumbuhan Mikroba & - & - & - & - & - & - & - & - \\
\hline
\end{tabular}

Keterangan: $(\mathrm{v})=$ terdispersi homogen

$(-)$ = tidak terjadi

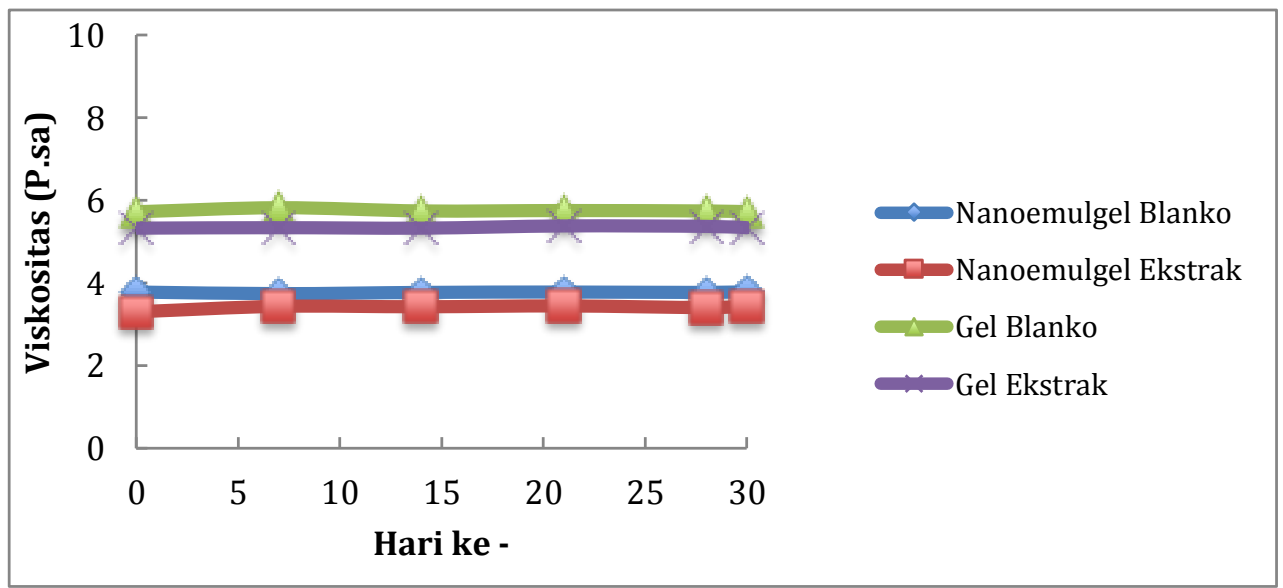

Gambar 2. Grafik Uji Stabilitas dari Viskositas Nanoemulgel 


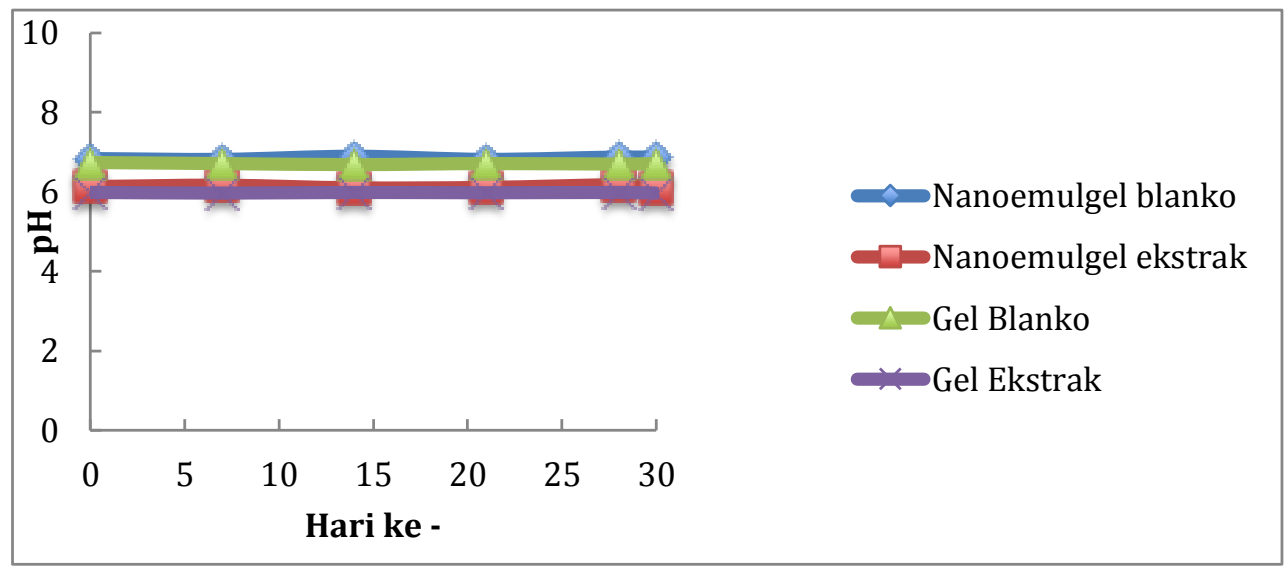

Gambar 3. Grafik Uji Stabilitas dari pH Nanoemulgel

\section{KESIMPULAN}

Berdasarkan hasil penelitian yang telah dilakukan maka dapat disimpulkan bahwa gelling agent yang sesuai sebagai pembawa sediaan nanoemulgel adalah viskolam MAC 10 20\% dan telah teruji stabil selama penyimpanan 30 hari pada suhu $40^{\circ} \mathrm{C}$.

\section{UCAPAN TERIMA KASIH}

Ucapan terima kasih kami berikan kepada Balai Besar Penelitian dan Pengembangan Tanaman Obat dan Obat Tradisional Kementerian Kesehatan RI yang telah memfasilitasi sehingga penelitian ini dapat berlangsung, Lembaga Penelitian dan Pengabdian pada Masyarakat Universitas Mulawarman atas bimbingan yang telah diberikan kepada kami, Fakultas Farmasi Universitas Mulawarman atas fasilitas yang telah diberikan kepada kami sehingga kami dapat melaksanakan kegiatan penelitian dengan lancar. Terakhir kami ucapkan terima kasih kepada seluruh pihak yang telah banyak membantu dalam penelitian ini.

\section{DAFTAR PUSTAKA}

[1]. Setyaningrum, N.L. 2013. Pengaruh Variasi Kadar Basis HPMC Dalam Sediaan Gel Ekstrak Etanolik Bunga Kembang Sepatu (Hibiscus rosa sinensis L.) Terhadap Sifat Fisika dan Daya Antibakteri pada Staphylococcus aureus. Naskah Publikasi. Fakutas Farmasi Universitas Muhammadiyah Surakarta.

[2]. Madan, J., dan Singh, R. 2010. Formulation and Evaluation of Aloevera Topical Gels. Int.J.Ph.Sci. 2 (2). 551-555.

[3]. Arikaumala, J., Dewantara, I.G.N.A., dan Wijayanti, N.P.A.D. 2013. Optimasi HPMC Sebagai Gelling Agent Dalam Formula Gel Ekstrak Kulit Buah Manggis (Garcinia mangostan L.). Jurnal Farmasi Udayana. Jurusan Farmasi Fakultas Matematika dan Ilmu Pengetahuan Alam Universitas Udayana. Bali.

[4]. Suardi, M., Armenia dan Anita, M. 2008. Formulasi dan Uji Klinik Gel Antijerawat Benzoil Peroksida-HPMC. Skripsi. Fakultas Farmasi Universitas Udayana. Denpasar.

[5]. Rawlins, E.A. 2003. Bentleys of Pharmaceutics. Edisi Kedelapanbelas. Baillierre Tindal. London. Hal 22-35.

[6]. Tranggono, Retno, I., Latifah, Fatmah. 2007. Buku Pegangan Ilmu Pengetahuan Kosmetik. PT. Gramrdia Pustaka Utama. Jakarta.

[7]. Ansari, S.A. 2009. Skin pH and Skin Flora. In Handbook of Cosmetics Science and Technology. Edisi Ketiga. Informa Healtcare USA. New York. Hal 222-223. 